\title{
The Development Of Media Based Computer To Increase Learning Independence And The Treasury Of Madurese Vocabularies
}

\author{
Yudia Pertiwi \\ Universitas Negeri Surabaya \\ Surabaya, Indonesia \\ yudiapertiwi@mhs.unesa.ac.id
}

\begin{abstract}
Utilizing computer media allows the learners to learn according to their ability and their speed in an understanding of knowledge and information that is presented. The ability of the computer to serve back information that is needed by a user can help learners who have learning speed slow.

Learners are familiarized to search the meaning of the word in a dictionary. To activate the vocabulary is by using vocabulary or word continuously and repeatedly so that the word becomes active and alive in the memory of learners.

The data processing from the result of the research by using the computer program SPSS 20.0 for Windows Evaluation Version. The result of the data analysis are (1) can increase learning independence in learners, (2) can increase the treasury of vocabularies in learners, (3) can increase the result of learning in learners at VII Class SMP Negeri 2 Pegantenan Pamekasan.
\end{abstract}

Keywords—Madurese vocabularies; language

\section{PREFACE}

The mastery of Madurese vocabularies is included the student's ability in understanding, mentioning, dan indicating vocabulary in general vocabulary, particular vocabulary, and basic vocabulary by using Ondhâgghâ Bhâsa Madhurâ (a language of Madurese vocabularies by using language levels). To activate the vocabulary is by using vocabulary or word continuously and repeatedly so that the word becomes active and alive in the memory of learners. The effort to optimize the mastery of vocabulary in speaking skills and writing must be developed continuously so that gives an overview that skills and quality of language in their writing are very good and varied in accordance the rules of language that is good and right.

The condition of learning the Madurese language in this time have some obstacles are (1) students less pay attention to the rules of language that include pronunciation, spelling and punctuation, vocabulary, structure, paragraph, and discourse. In understanding levels, the skill that should be exceeded is speaking and writing. in the fact there are many students can speak well but can't write using the Madurese language rightly; (2) there is belief that the Madurese language doesn't need to be learned because have been used as media of communication in every day. Finally, the students are having difficulty when communicating with their teacher and the older people in using Madurese language as well and right; (3) the lack of student's interest to learn and memorizing Madurese language vocabulary compared to learn foreign language; (4) the minimal literature about how to learn Madurese language as well and rightly; (5) the language learning of Madurese language is inclined monotonous (speech or talk, question and answer, and giving an assignment) makes student doesn't interested to follow Madurese language lesson; (6) the lack of media of learning that attractive, interactive, and modern which are able to attract students in learning Madurese language; (7) the student's awareness to preserve local culture and wisdom through the language of Madura is very low.

One of the learning media that is used in this era is a media-based computer. By using, media are expected the process of learning can last active assimilation, accommodation, and organize into cognitive structure[1]. Remember that the important meaning of the concept in learning Madurese language activity and based on the fact that obtained in the field so the research and development media in the learning based computer is needed to fulfill the purpose in learning[2].

The basic consideration of the use of computer media in improving learning independence and add treasury of Madurese vocabularies in vii class SMPN 2 Pegantenan Pamekasan are : (1) the is an incompatibility between patterns learning and the characteristics of the students. The application of the old pattern (traditional pattern) that focused on teachercentered can make learning condition become boring, not interesting, and make the student surfeited when the teacher explained, (2) the characteristic of subjects need the suitable learning media with the characteristic of the student so that can achieve the goal of learning, (4) there is a previous research that give reference that learning with the development of media-based computer will take place effectively, efficient and have fun[3].

\section{REVIEW OF RELATED LITERATURE}

\section{A. The Development Model}

This research uses the development model Borg and Gall that contains guide systematic the steps that are done by the researcher to make a product that is designed to have the eligibility standards[4]. 
Conceptually, the research approach and development include general steps [5]: 1) research and collecting information, 2) planning, 3) the development of the formatted product an early, 4) trials early, 5) repairing, 6) trials field, 7) revising product, 8) validation test, 9) the final repair, 10) spreading widely the product or model that is developed.

\section{B. The Result of Trials Development Product}

1. Trials Of Individuals

From the result of data from trials of individuals that consist of 6 people, students of SMPN 2 Pegantenan has obtained the value of the average percentage toward product learning media based computer by $90 \%$, based on the coefficient of the level of achievement so, this value is on qualifying: highest.

2. Trials Of Large Group

From the result of data from trials of a large group that consist of 17 people, respondent has obtained the value of the average percentage toward product learning media based computer by $88 \%$, based on the coefficient of the level of achievement so, this value is on qualifying: 'high'.

3. The Result Of Trials Development Product Reliability Test of a control class and experimental class for Pre Test and Post Test question

Based on the result of reliability test obtained value Cronbach's alpha for Pretest question in control class by 0,942 that value is higher than 0,20 it means that all of the pretest questions from control class is reliable. It also for pre-test and post-test on an experimental class that value is higher than 0,20 so that has to be said the value is reliable.

4. The test of level difficulties in control class and experimental class for Pre Test and Post Test question

The test of level difficulties is indicated by index difficulties. This test of difficulties is used to know about [6]. Which the level of difficulties for each item of question can be categorized as follow:

1. The question with $\mathrm{P} 0,00$ until 0,30 is difficult questions

2. The question with $\mathrm{P} 0,30$ until 0,70 is medium questions

3. The question with $\mathrm{P} 0,70$ until 1,00 is easy questions

As for the result of the calculation for testing the level of difficulties be aware that the question for pre-test and post-test for control class and experiment have two categories are an easy and medium question. On control class, there are 4 easy question on pre-test and 1 easy question on a post-test question. It means that there is a decrease in the number of a question by easy criteria if it is seen from the proportion of the number of correct answers from each question for all student. Whereas for the experimental class, there is an increase question by easy criteria. That is 3 easy question on pre-test and
14 easy question on post-test. In other words, the experimental class increased scores on post-test that is more significant than control class.

5. The test of different power-on control and experimental class for Pre Test and Post Test

The test of level difficulties is indicated by index difficulties. This test of difficulties is used to know about the question whether easy, medium or difficult [6]. Which the level of difficulties for each item of question can be categorized as follow:

a. The question with $\mathrm{P} 0,00$ until 0,30 is difficult questions

b. The question with $\mathrm{P} 0,30$ until 0,70 is medium questions

c. The question with $\mathrm{P} 0,70$ until 1,00 is easy questions

As for the result, the calculation for testing the level of difficulties be aware that the question for pre-test and post-test for control class and experiment have two categories are an easy and medium question. On control class, there are 4 easy question on pre-test and 1 easy question on a post-test question. It means that there is a decrease in the number of a question by easy criteria if it is seen from the proportion of the number of correct answers from each question for all student. Whereas for the experimental class, there is an increase question by easy criteria. That is 3 easy question on pre-test and 14 easy question on posttest. In other words, the experimental class increased scores on post-test that is more significant than control class.

6. The test of different power-on control and experimental class for Pre Test and Post Test

Different power (D) is a size that indicates which shows how big the item of question is able to distinguish group with the high ability and group with low ability with determined as follow [7]:

a. D : $0,00-0,2=$ poor question (poor) to distinguish group with high ability and low ability.

b. D : $0,20-0,40=$ satisfactory question (satisfactory) to distinguish group with high ability and low ability

c. D : $0,40-0,70=$ good question (good) to distinguish group with high ability and low ability

d. D: negative question (negative) $=$ the question is not good to distinguish group with high ability and low ability.

The result of the research indicates that each pretest and post-test in each class have distinguishing power criteria in diverse. As much as 8 question pretest on control class is said bad in distinguishing the group with low ability and the group with high ability. Also, indicate that as much as 12 question post-test on experimental class bad in a distinguishing group of student's ability. It can be 
caused because an amount of $97 \%$ students include in the group of student with high quality.

7. Normality test

Result study has been seen that the data of result study and independent learning for control class and experimental class have distribution normal because p-value precious 0,055 for result study and 0,503 for independent learning, is higher than $\alpha=$ 0,05 .

Adobe Flash Madurese language increase the resulting study of student. using T-test two sides is also used for assessment of independence student on control class and experimental class. The hypothesis that is used is as follows:

H0: independence learning control class is same with independence learning experimental class.

$$
\mu_{1}=\mu_{2}
$$

$\mathrm{H} 1$ : independence learning control class isn't same with independence learning experimental class.

$$
\mu_{1} \neq \mu_{2}
$$

\section{The Discussion of Result of RESEARCH}

The result of structure independence value class control and experimental class obtained data that can give the conclusion that the use of learning media based computer give the impact of the positive change on the student independence learning.

In this research, against the alteration The mastery of Madurese vocabularies is included the student's ability in understanding, mentioning, and indicating vocabulary in general vocabulary, particular vocabulary, and basic vocabulary by using Ondhâgghâ Bhâsa Madhurâ (the language of Madurese vocabularies by using speech levels).

So, in another word, Adobe Flash media have a positive impact in independence and treasury vocabulary of the student.

\section{CONCLUSION AND SUGGESTION}

\section{A. Conclusion}

Based on the result of the research study and the result of the research discussion so that can be concluded that :

1. The result of the feasibility that obtained from media experts indicates that media-based computer proper to be used.

2. From some test analysis that has been done by the researcher is proven effective that :

a. The result of the development of learning media based computer can be able to increase independence learning of students at VII class of SMPN 2
Pegantenan Pamekasan in independence to other people, have self-confidence, discipline, be responsible, Behave or do something based on their own initiative, and doing self-control.

b. The result of the development of learning media based computer can be able to increase the mastery of Madurese vocabularies the subject matter pronunciation vocabulary by using Ondhâgghâ Bhâsa Madhurâ. the mastery of Madurese vocabularies is student's ability in understanding, mentioning, dan indicating vocabulary in general vocabulary, particular vocabulary, and basic vocabulary by using Ondhâgghâ Bhâsa Madhurâ (the language of Madurese vocabularies by using speech levels) at VII class of SMPN 2 Pegantenan Pamekasan.

\section{B. Suggestion}

Based on the result of the research study and the result of the research discussion so that can be asked that :

1. Advice utilization:

a. The result of the development of learning media based computer can be used as a reference as variations of product media of learning.

b. Students independence learning can be excited by designing a learning model that involves student to interact directly in independently or in the group.

\section{Advice dissemination}

The dissemination result of the development learning media based computer. there is something that should be revised by adding sound effects to get ideal product media based on the principle of the delivery of a message and can be socialized to all teacher through the school and student to can be made as one of the alternative sources of learning.

3. Suggestion for further development

To be able to develop product more can be done on themes of Madurese language learning or other subjects.

\section{REFERENCES}

[1] A. Arsyad, "Media Pembelajaran, ed. rev," Jakarta PT. Raja Graf. Persada, 2013.

[2] Y. Miarso, "Definisi Teknologi Pendidikan/Satuan Tugas Definisi dan Terminologi AECT," Jakarta: Rajawali, 1986.

[3] C. Wijaya and A. T. Rusyan, Kemampuan dasar guru dalam proses belajar mengajar. Penerbit PT Remaja Rosdakarya, 1991.

[4] W. R. Borg and M. D. Gall, "Educational research an introduction. New York and London." Longman, 1983.

[5] S. Arikunto, "206. Prosedur Penelitian Suatu Pendekatan Praktik," Jakarta PT RinekaCipta, 2010.

[6] A. Suharsimi, "Prosedur penelitian suatu pendekatan praktik," Jakarta: Rineka Cipta, 2006

[7] B. H. Douglas, "Prinsip Pembelajaran dan Pengajaran Bahasa," Pers. Educ. Inc, 2007. 